\title{
Correction to: Energy replacement diminishes the postprandial triglyceride-lowering effect from accumulated walking in older women
}

\author{
Masashi Miyashita 1 D $\cdot$ Yuka Hamada ${ }^{2,3} \cdot$ Kyoko Fujihira $^{2,3} \cdot$ Chihiro Nagayama $^{2} \cdot$ Masaki Takahashi $^{4}$. \\ Stephen F. Burns ${ }^{5}\left(\right.$ ) Alice E. Thackray ${ }^{6}(\mathbb{D})$. David J. Stensel ${ }^{6}(1)$
}

Published online: 9 May 2020

(c) Springer-Verlag GmbH Germany, part of Springer Nature 2020

\section{Correction to: European Journal of Nutrition https://doi.org/10.1007/s00394-020-02234-z}

The original version of this article unfortunately contained a mistake. The error of NEFA AUC values in Table 3 (mean and $95 \% \mathrm{CI}$ ) and the main text (effect size and $95 \% \mathrm{CI}$ ).

In "Postprandial serum/plasma concentrations" section, second sentence of the third paragraph should read as:
For NEFA $(\mathrm{ES}=0.482$, main effect of trial $p<0.0005)$ the AUC was lower on the accumulated walking with energy replacement trial than the control $(95 \%$ CI -0.065 to $0.005 \mathrm{mmol} / \mathrm{L} \mathrm{h}, p<0.0005)$ and the accumulated walking ( $95 \% \mathrm{CI}-0.111$ to $-0.037 \mathrm{mmol} / \mathrm{L} \mathrm{h}, p<0.0005$ ) trials.

The corrected Table 3 placed in the following page.

The original article can be found online at https://doi.org/10.1007/ s00394-020-02234-z.

Masashi Miyashita

m.miyashita@waseda.jp

1 Faculty of Sport Sciences, Waseda University, 2-579-15

Mikajima, Tokorozawa, Saitama 359-1192, Japan

2 Graduate School of Sport Sciences, Waseda University,

Tokorozawa, Saitama 359-1192, Japan

3 Research Fellow of Japan Society for the Promotion of Science, Tokyo 102-0083, Japan

4 Organization for University Research Initiatives, Waseda University, Singapore 139651, Singapore

5 Physical Education and Sports Science Academic Group, National Institute of Education, Nanyang Technological University, Singapore 637616, Singapore

6 National Centre for Sport and Exercise Medicine, School of Sport, Exercise and Health Sciences, Loughborough University, Leicestershire LE11 3TU, UK 
Table 3 The time-averaged serum non-esterified fatty acids (NEFA), 3-hydroxybutyrate (3-OHB), and plasma insulin and glucose area under the curve (AUC) values over $8 \mathrm{~h}$ after the consumption of

\begin{tabular}{|c|c|c|c|c|c|c|}
\hline Trial & Control & $\begin{array}{l}\text { Accumulated walk- } \\
\text { ing }\end{array}$ & $\begin{array}{l}\text { Accumulated walk- } \\
\text { ing with energy } \\
\text { replacement }\end{array}$ & $\begin{array}{l}\text { Control vs accu- } \\
\text { mulated walking, } \\
95 \% \mathrm{CI}^{\mathrm{a}}\end{array}$ & $\begin{array}{l}\text { Control vs accumu- } \\
\text { lated walking with } \\
\text { energy replacement, } \\
95 \% \mathrm{CI}^{\mathrm{a}}\end{array}$ & $\begin{array}{l}\text { Accumulated walking } \\
\text { with energy replace- } \\
\text { ment vs accumulated } \\
\text { walking, } \\
95 \% \mathrm{CI}^{\mathrm{a}}\end{array}$ \\
\hline $\begin{array}{l}\text { NEFA AUC } \\
(\mathrm{mmol} / \mathrm{L} \mathrm{h})\end{array}$ & $0.31(0.12)$ & $0.35(0.12)$ & $0.28(0.11)$ & -0.01 to 0.08 & -0.07 to $-0.01 * *$ & 0.04 to $0.11 * * *$ \\
\hline $\begin{array}{r}\text { 3-OHB AUC } \\
(\mathrm{mmol} / \mathrm{L} \mathrm{h})\end{array}$ & $0.03(0.01)$ & $0.04(0.02)$ & $0.03(0.02)$ & -0.01 to 0.01 & -0.01 to 0.01 & -0.01 to 0.01 \\
\hline $\begin{array}{r}\text { Insulin AUC } \\
(\mathrm{pmol} / \mathrm{L} \mathrm{h})\end{array}$ & $94.8(75.4)$ & $81.3(73.5)$ & $108.3(76.9)$ & -26.47 to $-0.36^{*}$ & -11.23 to 38.38 & -51.67 to $-2.31^{* * *}$ \\
\hline $\begin{array}{c}\text { Glucose AUC } \\
(\mathrm{mmol} / \mathrm{L} \mathrm{h})\end{array}$ & $6.11(1.00)$ & $6.05(1.20)$ & $6.01(1.01)$ & -0.43 to 0.32 & -0.29 to 0.10 & -0.32 to 0.39 \\
\hline
\end{tabular}

Values are mean (SD) for $n=17$. Means were compared using one-factor ANOVA and post hoc analysis was adjusted for multiple comparisons using the Bonferroni method

${ }^{\mathrm{a}} 95 \%$ confidence interval (CI) of the mean absolute difference between the experimental conditions. Analysis revealed a main effect of trial for NEFA $(p<0.0005)$ and insulin $(p=0.018)$

Post-hoc analysis of the main effect of trial: $* p<0.05$ between accumulated walking and control; $* * p<0.05$ between accumulated walking with energy replacement and control; $* * * p<0.05$ between accumulated walking and accumulated walking with energy replacement 